\title{
Orang Asli Socio-Development Index Instrument in Malaysia
}

\author{
Syaaibah Zulkipli ${ }^{{ }^{*}}$, Mohd Nuri Al-Amin Endut ${ }^{2}$, and Mohd Ridhuan Tony Lim Abdullah ${ }^{3}$ \\ ${ }^{1,2,3}$ Department of Management and Humanities, Universiti Teknologi PETRONAS, 32610 Bandar \\ Seri Iskandar, Perak, Malaysia
}

\begin{abstract}
Orang Asli is among the marginalized communities in Malaysia which perceived to have a very low performance in various social indicators. Though of numerous efforts of transformational and development programs initiated by the government, there are no specific measurement tool or instrument to evaluate the performance these initiatives as to verify the effectiveness of government policies. This paper aims to propose an index instrument to assess the socio-development of Orang Asli in Malaysia. The development of this index will employ Fuzzy Delphi Method (FDM) to determine the indicators and sub-indicators of the index, and Analytical Hierarchy Process (AHP) to determine the weightage of each indicators and sub-indicators. The proposed Orang Asli socio-development index is expected to be the base of government strategies and action plan to provide a better living quality to Orang Asli community in Malaysia.
\end{abstract}

\section{Introduction}

The Orang Asli known as the earliest community a small group of indigenous peoples in the Peninsular Malaysia. The Orang Asli is a general term for the still-tribal and recently tribal population of Peninsular Malaysia. The Orang Asli represent 18 different tribal groups and each of these tribes has its own languages, cultures, economic, religion, social organization and physical characteristics (Carey, 1976). All these sub-groups are depending on their subethnicity and the location. There have three main ethnics namely; 1) Negrito, 2) Senoi and 3) Proto Malay. Table 1.1 below shows the ethnic classification of Orang Asli.

Table 1. Categories of ethnics Orang Asli in Peninsular Malaysia (JAKOA, 2021)

\begin{tabular}{|l|l|l|}
\hline Senoi & Melayu-Proto & Negrito \\
\hline Semai & Temuan & Kensiu \\
Temiar & Semelai & Kintak \\
Jahut & Jakun & Jahai \\
CheWong & Kanaq & Mendriq \\
Mah Meri & Orang Kuala & Lanoh \\
SemoqBeri & Orang Seletar & Bateq \\
\hline
\end{tabular}

\footnotetext{
* Corresponding author: syaaibah@gmail.com
} 
According to Nik Hassan (1990), although Malays and Orang Asli have a similar origin, but their beliefs, social, linguistic and economic are different. This is because the historical context and the reaction to change. However, there are still exist local communities that have not benefited from adequate and appropriate social infrastructure (Fadzil, Ibrahim, Awang, Zainol \& Edo, 2016). Geoffrey (2004) mentions that the term was recognized in 1960 as a replacement for the previously named "Malaysian Aborigines". In Malaysia, Orang Asli has been recognized as 'bumiputera' and their rights protected by a legal act.

The Department of Orang Asli Affairs (JHEOA), known as the Department of Orang Asli Development (JAKOA) in the late 1950's, the government began to give serious attention to the communities of Orang Asli in the development of the country (Kassim et. all, 2017). In line with JAKOA's mission to develop the socio-economic and quality of life by preserving the heritage, culture and identity of Orang Asli, JAKOA also has organized programs for Orang Asli's development (Dahlan et. all, 2014). The government has created reorganization programme of the Regroupment Planning Scheme called as RPS (Rancangan Pengumpulan Semula) for Orang Asli to live in groups and facilitate the development agenda, for example in the rainforest along the Titiwangsa Mountain Range. In addition, RPS also integrates the lives of Orang Asli people into modern life with basic infrastructure (Salleh \& Ahmad, 2009).

\section{Problem Statement}

The efforts of the government and JAKOA to transform the Orang Asli communities show some changes are taking place in all aspects of the life of their communities, including economic, educational, health, social and cultural activities. In essence, the changing is due to the concern of certain parties, especially the government in trying to help the Orang Asli communities to get out of the old cocoon with various measures. In fact, the conscience of society itself has also led to the modernization of the mentality towards a better development and quality of life in line with the field of globalization (Farah, 2011).

Despite of all the modernization and efforts from the government agencies, there are many claims that fail to agree with them. According to Mohd Izzuddin (2010), Orang Asli is still struggling with the basic problems of development such as poverty, dropping in education, health, basic facilities and many more. In addition, Izawati (2016) mentioned that Orang Asli also facing the land and resource rights between state government.

In the meantime, all of these problems have become a concern for them because education, health, social facilities and land rights still do not have a solution to this problem. Thus, this study extracted to develop index the socio-development of Orang Asli in Perak to measure the index which show the strength and weakness of specific indicators.

Recognizing all efforts made by the government are appropriate and consistent with the current era, a comprehensive form of assessment must be taken to examine the level of achievement and effectiveness of Orang Asli development in Malaysia. The government through JAKOA, must also carry out on all the policies implemented to see its impact to the Orang Asli populations. One of the best research mechanisms for this purpose is the development of an index development which can provide a comprehensive assessment in a qualitative and quantitative manner.

\section{Literature Review}

\subsection{The Orang Asli}

There are many studies on Orang Asli socio-development such as in area of education, quality of life and poverty has been conducted by other researcher. One of the approaches used is that of social exclusion. But all these research does not address a more structure model of socio-development that consist of valid and verified indicators and sub-indicators 
Based on previous research showed, the Orang Asli are among the most backward communities and low in the social indicators. For example, Zainal Abidin (2003) mention the official statistics hardcore poor of Orang Asli is 35.2 percent. This is showed that the social and economic development with basic infrastructure of Orang Asli lag far different with the other communities in Malaysia.

Rohayu \& Noor Sharipah, (2013) mention that, Orang Asli is known as a community who is depending on natural resources by undergoing survival activities. Moreover, around $86 \%$ of them still working on their own. For instance, there have some of Orang Asli tribes are consolidated to a modern place, so that their socialization and development has achieving the objectives of the state government, in particular with regard to the control and exploitation the natural resources.

A study by Mazdi Marzuki et. all (2014) showed that, Orang Asli in Malaysia are far behind in educational achievement. Besides that, a study by William Hunt (1993) suggested various problems and challenges faced by Orang Asli in achieving progressive community such as poverty, difficulty to asset production, lack of education and political power. This leads to a barrier for the researchers in knowing the Orang Asli socio-development index instrument in Malaysia.

This raises the question the impact of Orang Asli communities on their more positive or negative character. Orang Asli community's willingness and resilience to accept development is essential to this issue, because a community must have social, economic and moral resilience to be competitive and establish prospects compatible with the current environment and ready to face various obstacles and challenges. Various policies are provided by the state government to help develop the socio-development and economic quality life of the Orang Asli in Malaysia.

According to Khor (2001), there have some of the Orang Asli resettlement have been provided with the various basic facilities through the implementation of development projects by the gvernment. In Malaysia's Ninth Plan, the government made a commitment to develop and improving the life of Orang Asli (Kamarulzaman \& Osman, 2008). They mention that many Orang Asli children are left behind due to lack of basic facilities such as no transportation to school in their area. For instance, today the government has created a settlement for Orang Asli communities filled with various basic facilities.

Therefore, the affairs of Orang Asli, JAKOA plays an important role in ensuring that economic development and social development will improve the well-being of Orang Asli through educational programs and others (Nicholas, 2005). The education is further emphasized by Mohd Tap (1990), who stated that education is a main focus in the development of Orang Asli.

\subsection{The Index Studies}

Various studies of index related to Orang Asli have been carried out by other researchers. The most common measures used by researchers to describe the quality life of Orang Asli relate to basic equipment such as water supplies, electricity, roads, education, standard of living and others (Harun \& Idris, 2012). Based on previous studies, among the index conducted are the problematic quality of life index and the multidimensional poverty index (MPI) using parameters standard. Studies by Churchill (1979) and DeVellis (1991), the developed index is derived from four main stages, it is 1) the process of skills generation, 2) the process of verifying skills, 3) reliability testing and 4) development of the skills of the index (Shariff \& Abidin, 2015).

The index studies began in the early 2000s are a form of research that has become increasingly popular in recent times. There are few examples of index studies that have been carried out in Malaysia as well as abroad: 
1.1 Social Protection Index (SPI) - Asian Development Bank (ADB) 2006

1.2 Human Development Index (HDI) - United Nations Development Program (UNDP).

1.3 Global Peace Index (GPI) - The Institute for Economics and Peace (IEP), 2008.

1.4 Inclusion Index - Center of Excellence for National Security (CENS), Singapore 2007.

1.5 Community Tension Index (EMP) - Department of National Unity (JPNIN) Malaysia 2010.

1.6 Socio-Religious Harmony Index - IKIM, UTP, UPM, USAS 2017

1.7 Kelantan Socio-indigenous Index - UPT, State Education Exco Kelantan.

The definition of an index according to the Oxford Dictionary is, the sign or measurement of something. The meaning is giving certain magnitude of a physical property or phenomenon to be measured. From that, the answers can be discovered. One of the indices for the Social Development Index (SDI) was developed by the Asian Development Bank (ADB) in 2006. The objective of this index is to measure the level of social protection in the countries of Asia Pacific. The index uses five key elements to describe social protection, including the labor market program, the social insurance program, social assistance and welfare program, microcare, child care and child protection program (Blumer, Wood \& Weber, 2006).

There is also Human Development Index (HDI) which was developed within the framework of the United Nations Development Program (UNDP). This index was created by combining indicators of life expectancy, education and income. HDI set the minimum and maximum for each dimension known as the goal post, then, indicate the position of each country relative to the goal post, expressed in value between 0 and 1 (Trabold-Nübler, 1991).

In addition, there is also an index of security measures called as Global Peaceful Index (GPI) developed by the Institute of Economics and Peaceful (IEP). This index is published in every year and has been recognized as a benchmark in measuring world security since 2008. The index uses qualitative and quantitative indications in eight interdependent taxonomies. The index aims to identify the factors that create a secure society covering 164 countries (Economy and Security, 2013).

Besides that, there have the Department of National Unity and Integration (DNUI) which developed an index named the "Community Tension Index (CTI)". This index aims to measuring the level of social tension among Malaysians. As per reported quarterly, this index is the main benchmark for measuring the level of social tension in people since 2010 . According to data from the Royal Malaysian Police (RMP), the Malaysian Armed Forces (MAF) as well as press reports, the CTI takes an account current indications such as demonstrations, racial conflict and related matters to that end.

Therefore, this paper aims to propose an index instrument to assess the socio-development of Orang Asli in Malaysia. By applying the index instrument to the Orang Asli in Malaysia, this study able to reveal the weightage of each indicators and sub-indicators of the index. Besides that, the cooperation and assistance from others especially from government, JAKOA, NGO's and other stakeholders to ensure the livelihood of Orang Asli to be more comprehensive and able to bring and voice out the fate of Orang Asli in the parliament.

\section{Methodology}

This paper aims to develop a socio-development index instrument of Orang Asli in Malaysia. Therefore, to achieve the objectives of this study, this study will conduct with two stages: 


\subsection{Determination Indicators and Sub-indicators of the Index Instrument for Socio-Development of Orang Asli in Malaysia}

The strengths and weaknesses of composite indicators are derived from the quality of the underlying variables (Nardo et al., 2008), the indicators and sub-indicators for this instruments is based on opinion experts through Blurred Delphi (FDM) methods. This method is based on a theoretical framework and a review of the literature before being presented to the experts. The core indicators and sub-indicators have been discussed previously. The Fuzzy Delphi introduced by Kaufmann and Gupta (1988 is a combination of the theory and techniques of fuzzy sets by Duzhi (Murray, Pipino and Gigch, 1985).

This method is an analytical decision-making method which integrates the 'fuzzy' theory into the traditional Delphi method. The Delphi method (Linstone \& Turoff, 2002) is a decision-making method that includes a survey to generate an expert opinion on the questions studied. The Delphi method has been widely used to select performance indicators in various fields, but it requires several investigations to reach the diversity of opinions of experts and experts required and forced to change their minds to respect the average values of all expert advice.

\subsection{Determination of the Index Instrument for Socio-Development of Orang Asli in Malaysia}

This includes the development of the index for socio-development of Orang Asli in Malaysia. It is divide into two parts, that is determination of the weighting value of each of the index indicators using Hierarchical Analytical Process (AHP) and the second is determine the value index instrument for socio-development of Orang Asli in Malaysia.

The first part is The Hierarchical Analytical Process (AHP), since its creation, has been the method for decision makers and researchers; and it is one of the most frequently used critical decision-making tools. Many high-quality studies have been published based on AHP processes, including AHP applications in various fields, including policy planning, best alternative selection, resource allocation, conflict resolution, etc. AHP's specialty is the ability to integrate with different techniques such as linear programming, quality functional implementation, fuzzy logic, etc. The AHP measures from this study were applied to calculate the weighting effect of an indicator and a sub-indicator using relative comparisons with other indicators.

Secondly, to determine the value index instrument for socio-development of Orang Asli in Malaysia. In order to obtain the values Index Instrument for Socio-Development of Orang Asli in Malaysia, the questionnaire was distributed to all the experts to assess the level of development and general success of the Orang Asli people in each sub-indicator by responding in a Likert scale 1 to 5 . The Likert scores for each sub-indicator of each respondent, will be averaged and multiplied by the weighting factor to produce the value index.

\section{Significant of the Study}

The significant of this study is important for the government agencies especially JAKOA to identify the socio-development of Orang Asli in order to fulfil the needs of Orang Asli in Malaysia. Besides that, this study may contribute to improve their quality life in every aspect especially in the integration of social, political, economic, health and educational. Hence, the index instruments to be developed can be used periodically over a long period of time to measure the impact and success of Orang Asli development. On the other hand, the study is crucial in order to identify the real situation Orang Asli as well as strengthening the relationship with the affairs of the Orang Asli and JAKOA. 


\section{Conclusion}

With the completion of this study, it is hoped that the sustainability in community development among Orang Asli will be more measurable than a simple slogan presentation. This study will be a stepping stone to move forward in strengthening the confidence of Orang Asli comunities in the capacity of a state government to play a role in the development of the Orang Asli communities with other communities. The efforts and responsibilities of all parties involved in the management of social development such as health, education, modernization of social structures and economic and other development constitute a solid partnership for the development and administration of Orang Asli. In addition to this, it also helps to improve the quality of life of the Orang Asli communities.

The Orang Asli socio-development index instrument in Malaysia guarantees the sustainability of all policies, plans and strategic programs planned by the government as well as by JAKOA. The index instruments to be developed can be used periodically over a long period of time to measure the impact and success of Orang Asli development. The strategic plan based on the socio-development index is essential to guide the state government to focus on more critical areas according to the needs of Orang Asli. Focusing on these priorities indirectly opens the door to encounter other aspects of the development to the Orang Asli communities.

\section{REFERENCES}

Abdullah, M. F., Othman, A., Edo, J., \& Jani, R. (2019). Multidimensional Poverty Index of Marginalized Orang Asli in Terengganu, Malaysia. Pertanika Journal of Social Sciences \& Humanities, 27(2).

Blumer, B., Wood, J., \& Weber, A. (2006). Developing a Social Protection Index for Asia. Development Policy Review, 24 (1). 5-29.

Carey, Iskandar. (1976). Orang Asli: The Aboriginal Tribes of Peninsular Malaysia. Oxford University Press. Kuala Lumpur.

Dahlan, A. R. A., Ibrahim, J., Zakaria, N. S. A. B., Ishak, I. B., Rahim, N. N. B., \& Malek, N. A. B. A. (2014, November). eSoulKitchen program-Enhancing societal wellbeing and wealth creation for Orang Asli Community at Pos Selim, Perak. In The 5th International Conference on Information and Communication Technology for the Muslim World (ICT4M) (pp. 1-6). IEEE.

Fadzil, K. S., Ibrahim, W. S. W., Awang, S. N., Zainol, R., \& Edo, J. (2017). Masyarakat pribumi, infrastruktur sosial dan pembangunan terancang di Malaysia: Kajian penglibatan masyarakat Orang Asli di RPS Air Banun, Belum-Temengor, Perak. Geografia-Malaysian Journal of Society and Space, 12(10).

Farah Shaqhirah 2011. Kepentingan Pemuliharaan Warisan Kebudayaan Di Negara Malaysia. Taken 10 March 2017 from http://www.scribd.com/doc/52306655/Kepentingan-Pemuliharaan-WarisanKebudayaan-di-Negara-Malaysia.

Geoffrey, Benjamin. (2004). On Being Tribal in the Malay World. In: Benjamin Geoffrey and Cynthia in Tribal Communities in the Malay World; Historical, Social and Cultural Perspectives. Pp. 7-76. Leiden: IIAS. Singapore. ISEAS.

Harun, M. F. M., \& Idris, N. A. H. (2012). Kualiti Hidup Orang Asli: Pengukuran Melalui Indeks (The Quality of Life of Malaysian Aborigines: Measured with a Weighted Quality of Life Index for Orang Asli). Akademika, 82(1).indicator? Intereconomics, 26(5), 236-243. 
Ismail, H., \& Sa'ari, C. Z. (2005). Masyarakat Orang Asli dan pembangunan insaniah. Jurnal CITU, 1(2), 67-82.

Izawati Wook. (2016). The Orang Asli in Peninsular Malaysia and the Recognition of Their Land Rights Under the Aboriginal Peoples Act 1954. Malaysian Journal of Syariah and Law. Volume 4, 2016. ISSN: 1985-7454.

Juli Edo. 2001. "Tamadun Peribumi Malaysia". Dlm. Tamadun Islam dan Tamadun Asia. Kuala Lumpur: Penerbit Universiti Malaya.

Kassim, F., Jais, A. W., Hassan, Z. A., Yaacob, N. H., \& Mazlan, A. (2017). Perubahan Amalan Budaya Masyarakat Orang Asli. Proceedings of the International Conference on Islam, Development and Social Harmony in Southeast Asia.

Linstone, H. A., \& Turoff, M. (2002). The Delphi method: techniques and applications ebook. Newark: New Jersey Institute of Technology.

Mazdi Marzuki, Jabil Mapjabil dan Rosmiza Mohd Zainol. (2014). Mengupas Keciciran Pelajar Orang Asli Malaysia: Suatu Tinjauan ke Dalam Isu Aksesibiliti Sekolah. Malaysia Journal of Society and Space 10 Issues 2 (189-198). 2014. ISSN 2180-2491.

Malaysia, D.o.S. (1961). Dasar Kerajaan Berkanun Dengan Pentadbiran Orang Asli Semenanjung Malaysia, Kuala Lumpur: JHEOA.

Malaysia, D.o.S. (1991). Profil Orang Asli di Semenanjung Malaysia, Kuala Lumpur: JHEOA.

Mohd Tap, S. (1990). Planning and administration of development programmes for tribal peoples (the Malaysian setting). Kuala Lumpur: Department of Orang Asli Affairs.

Murray, T. J., Pipino, L. L., \& van Gigch, J. P. (1985). A pilot study of fuzzy set modification of Delphi. Human Systems Management, 5(1), 76-80.Orang Asli (pp. 47-58). Bangi: Penerbit UKM.

Nardo, M., Saisana, M., Saltelli, A., Tarantola, S., Giovannini, E., \& Hoffmann, A. (2008). Handbook on Constructing Composite Indicators: Methodoloy and User Guide.

Nicholas, C. (2000). The Orang Asli and the Contest for Resources. Indigenous Politics, Development and Identity in Peninsular Malaysia. International Work Groupon Indigenous Affairs. Copenhagen. Denmark.

Nicholas, C. (2005). Integration and modernization of the Orang Asli: the impact on culture and identity. 1st International Conference on the Indigenous People. Kuala Lumpur.

Rohayu Roddin \& Noor Sharipah Sultan Sidi (2013). Pembinaan Keupayaan Dalam Pelancongan Orang Asli: Satu Kajian Kes Dalam Komuniti Mah Meri. Proceeding of the International conference on Social Science Research, ICSSR 2013. ISBN 978-96711786-1-8.

Salleh, M. J., \& Ahmad, A. R. (2009). Kesedaran pendidikan dalam kalangan masyarakat Orang Asli. Bangi, Penerbit Universiti Kebangsaan Malaysia.

Shariff, N. M., \& Abidin, A. Z. (2015). Developing an index of the Malaysian tourism and hospitality graduates competencies. International Journal of Business and Society, 16(3).

Trabold-Nübler, H. (1991). The human development index - a new development

Williams Hunt, Anthony. (1993). Masyarakat Orang Asli Menghadapi Cabaran Pembangunan. Universiti Kebangsaan Malaysia. 